\title{
Solitary Fibrous Tumor of the Vagina with Potentially Malignant Features: A Case Report and Review of the Literature
}

\author{
Asuman Nihan HABERAL REYHAN
}

Department of Pathology, Başkent University Faculty of Medicine, ANKARA, TURKEY

\begin{abstract}
Extrapleural solitary fibrous tumors are being increasingly reported. The retroperitoneum, deep soft tissues of the proximal extremities, abdominal cavity, trunk, head and neck are among the most common extraserosal locations reported. A recurrent solitary fibrous tumor involving the vagina of a 25-year-old woman is reported. Microscopically, the tumor was hypercellular and composed of mitotically active spindle cells. Immunohistochemically, the tumor cells were positive for vimentin, CD34, and bcl-2. Four cases of solitary fibrous tumors involving the vagina have been reported previously. To the best of our knowledge, this is the first case with clinical and histological features suggestive of a malignant behavior.
\end{abstract}

Key Words: Solitary fibrous tumor, Vagina, Hemangiopericytoma, Female genital neoplasms

\section{INTRODUCTION}

The solitary fibrous tumor (SFT) is an uncommon spindle cell neoplasm of mesenchymal lineage that was first recognized as a distinctive pleural lesion in 1931. Extrapleural SFTs have been increasingly reported. The retroperitoneum, deep soft tissues of the proximal extremities, abdominal cavity, trunk, head and neck are the most common extraserosal locations reported $(1,2)$.

To the best of our knowledge, there have been only 4 previous case reports of a primary vaginal SFT in the English literature (3-6). In this article we describe a fifth case that recurred 4 years after the first excision. We believe that this is the first report describing an SFT of the vagina displaying clinical and histological features suggestive of a malignant behavior.

\section{CASE REPORT}

The patient was 21 years old when she felt a mass at the vagina around the hymen that was resected and histologically examined at another institution. Four years after the first excision, when she was 25 years old, she felt a mass at the same site again. A pelvic examination revealed a raised, firm, recurrent nodule measuring approximately $1.5 \mathrm{~cm}$ at the vagina around the hymen, and the mass was surgically reexcised. The recurrent tumor submitted for histopathological examination consisted of an irregularly shaped piece of $\tan$, rubbery, soft tissue measuring $1.5 \mathrm{x} 1.3 \mathrm{x}$

(Turk Patoloji Derg 2018, 34:186-189)

Received : 24.04.2015 Accepted : 11.06.2015
$0.8 \mathrm{~cm}$. The resection margins were carefully painted, and the specimen was submitted totally.

Microscopically, the lesion was a well-circumscribed nodule that was separated from the intact vaginal mucosa by a narrow fibrous zone (Figure 1). The tumor was hypercellular and consisted of spindle to ovoid cells with prominent nucleoli (Figure 2). No fascicles or a storiform pattern was seen. Areas of necrosis were not detected but there were up to 4 mitotic figures per each high power field (approximately 14 mitotic figures per 10 high power fields) (Figure 3). The neoplastic cells were diffusely positive for vimentin (Ab-2, NeoMarkers, Fremont, USA), CD34 (Ab-1, NeoMarkers, Fremont, USA), and $\mathrm{Bcl}-2$ protein (Ab-1, NeoMarkers, Fremont, USA) (Figure $4 A, B)$. They were only focally positive for pancytokeratin (PAN-CK Cocktail, Ab-2, NeoMarkers, Fremont, USA) and CD10 (Ab-2, NeoMarkers, Fremont, USA) and were negative for CD99 (Ab-1, NeoMarkers, Fremont, USA), SMA (Ab-1, NeoMarkers, Fremont, USA), S100 (DAKO, Glostrup Denmark), EMA (Ab-2, NeoMarkers, Fremont, USA), and HMB-45 (Melanoma (gp100)Ab-3, NeoMarkers, Fremont, USA). The surgical resection margins were clear. Ki-67 (Clone SP6, NeoMarkers, Fremont, USA) proliferation index of the tumor was $8 \%$.

A piece of tumor tissue was retrieved from the paraffin block for electron microscopic study. This was fixed first in $2.5 \%$ gluteraldehyde for $2-3$ hours; and then in $1 \%$ osmium tetraoxide $\left(\mathrm{OsO}_{4}\right)$ and dehydrated in a series of graded

Correspondence: Asuman Nihan HABERAL REYHAN Başkent Üniversitesi Tip Fakültesi, Patoloji Anabilim Dal, ANKARA, TURKEY

E-mail: asumannihan@yahoo.com Phone: +90 3122126591 


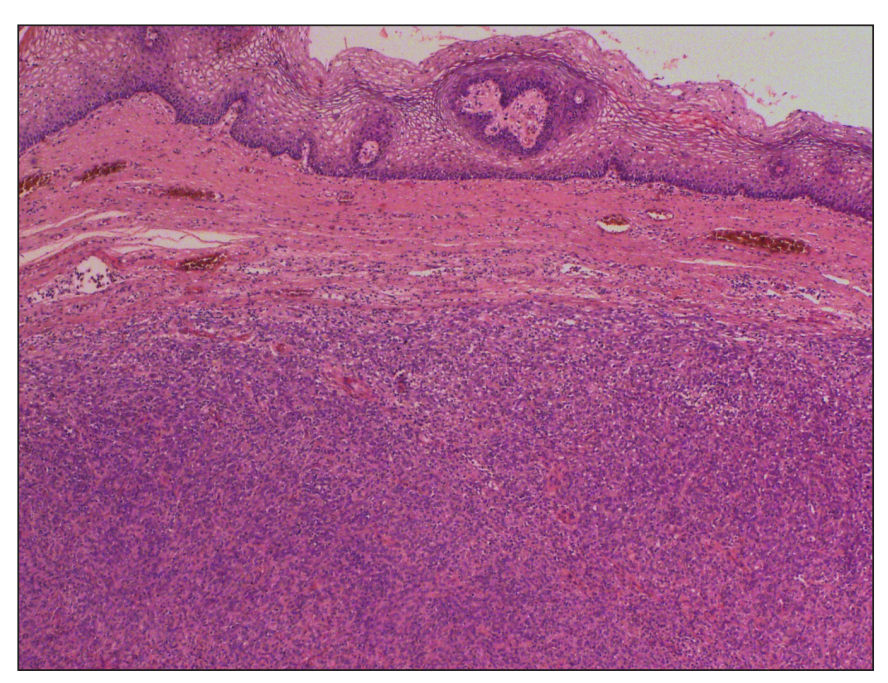

Figure 1: Well-circumscribed nodule separated from the intact mucosa by a narrow fibrous zone (H\&E; x40).

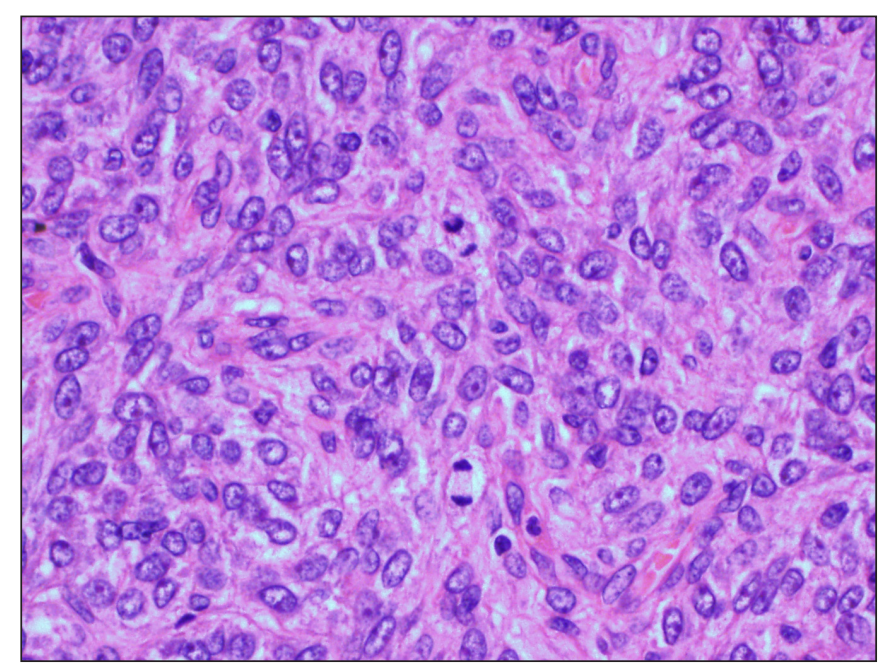

Figure 3: Two mitotic figures are seen in a high power field (H\&E; x400).

alcohols (25\%, 50\%, 75\%, 95\%, and absolute alcohol). After passing through propylene oxide, the specimens were embedded in araldyte CY 212, DDSA (2-dodecenyl succinic anhydride), BDMA (benzyldimethyl amine) and dibutylpytalate. Semithin sections were cut and stained with toluidine blue and examined with a light microscope. Ultrathin sections were stained with uranyl acetate and lead citrate and examined with LEO 906E EM transmission electron microscope. Ultrastructuraly, the tumor was hypercellular without a distinguishing organelle suggestive of a specialized line of differentiation (Figure 5). Specifically, Weibel-Palade bodies, prominent pinocytic vesicles or multiple cytoplasmic processes that might suggest certain other lines of differentiation were not seen.

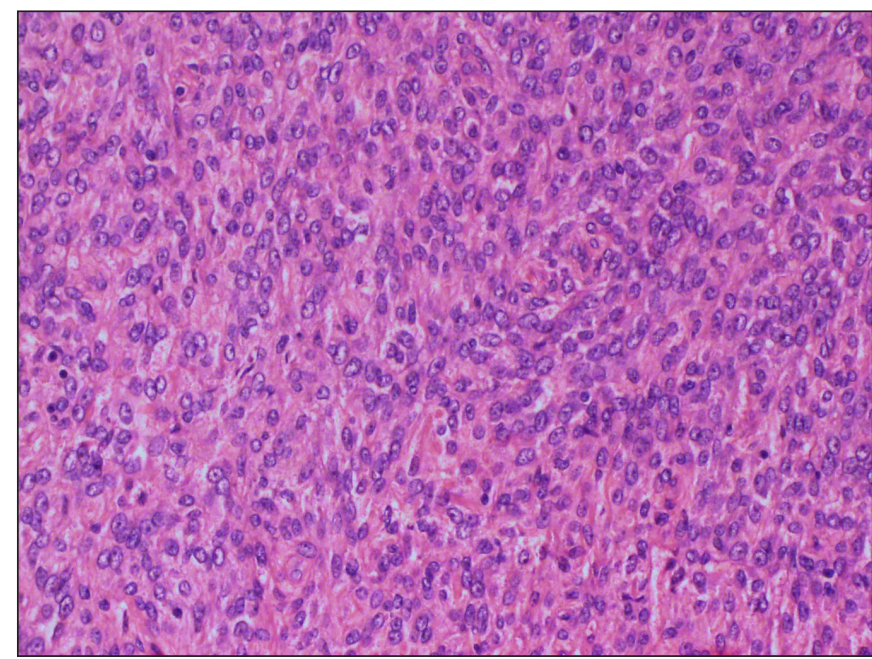

Figure 2: Hypercellular tumor that consisted of spindle to ovoid cells with prominent nucleoli (H\&E; x200).
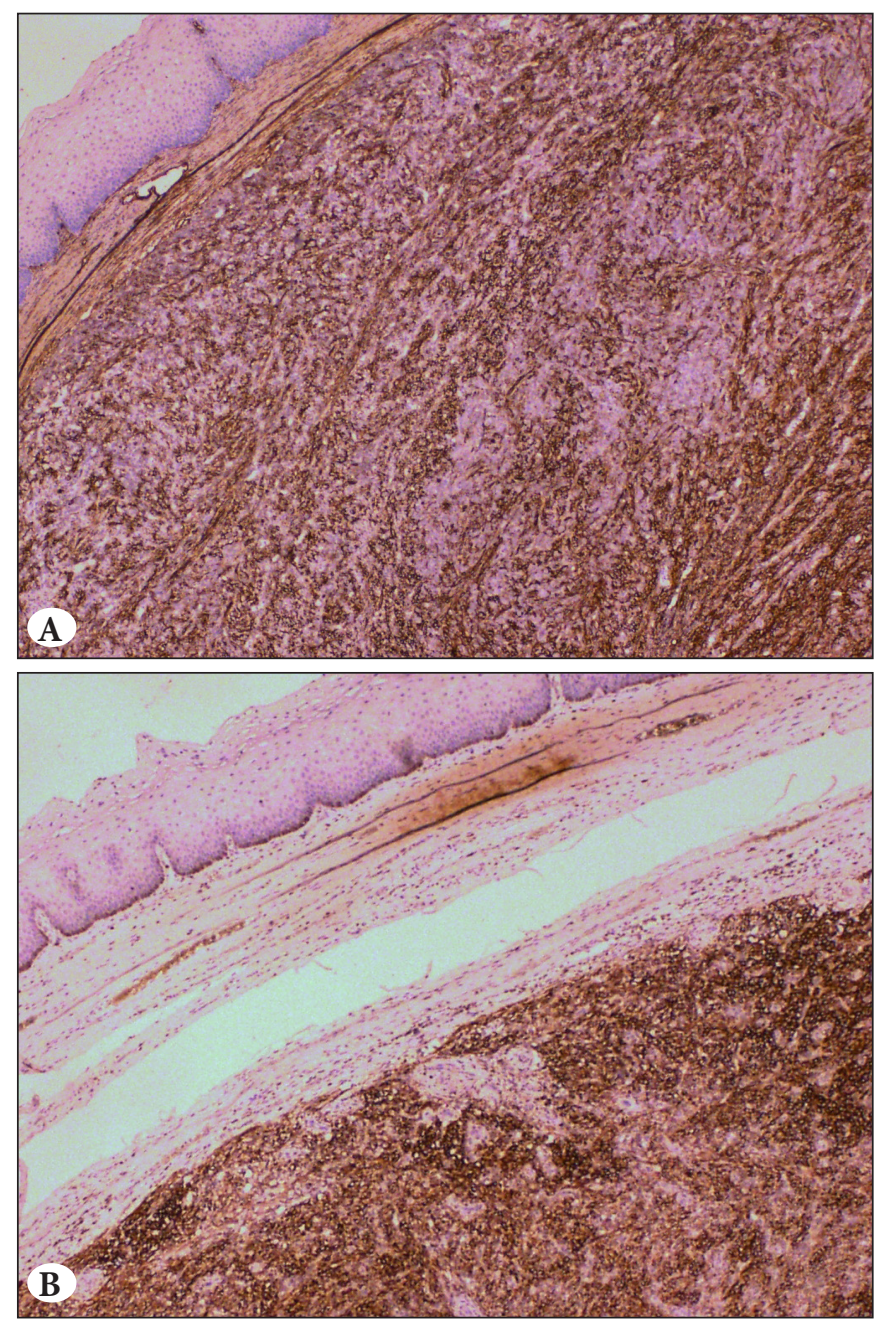

Figure 4: The neoplastic cells were diffusely positive for CD34 (A), and bcl-2 protein (B) (Immunoperoxidase x100). 


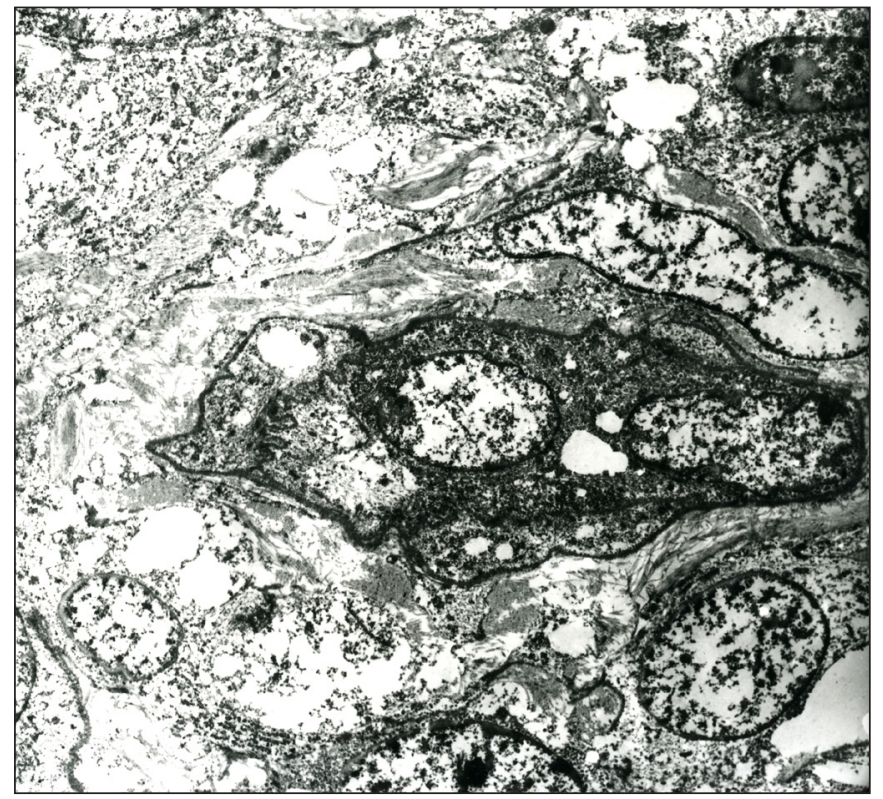

Figure 5: Ultrastructure of a tumor cell. No distinguishing organelle suggestive of a specialized line of differentiation is present (Electron microscopy x6000 magnification).

After the diagnosis of SFT with features suggestive of a malignant behavior, the patient was re-evaluated clinically and imaging studies were done to detect other recurrent or metastatic foci. These included abdominal and thoracal computerized tomography, pelvic ultrasonography, and a chest X-ray. Neither a recurrent nor a metastatic focus was detected. The patient is alive and free of disease 7,5 years after the second excision.

\section{DISCUSSION}

Solitary fibrous tumor (SFT) is a spindle-cell neoplasm most often presenting as a pleural-based tumor but it is increasingly recognized in other locations. To our knowledge, there have been only 4 previous case reports of a primary vaginal SFT in the English literature and some features of these were summarized in Table I.

SFTs are often asymptomatic and found incidentally in the course of evaluation for another medical problem. Histologic features overlap to a great extent with other tumors consisting mostly of spindle to ovoid cells and immunohistochemistry plays a significant role in diagnosis. The differential diagnosis of SFT includes neurofibroma, leiomyoma, spindle cell epithelioma, and myofibroblastoma of the vagina. Neurofibroma has wavy bundles of slender spindle cells with palisaded arrangement, has small nuclei, and is positive for S100 (5). Leiomyoma consists of interlacing fascicles of spindle cells with elongated nuclei; and is positive for desmin, actin, and caldesmon (5). Spindle cell epithelioma can be purely mesenchymal and histologically very similar to SFT and besides is also positive for CD34, bcl-2, and CD99 as is SFT. However, spindle cell epithelioma is strongly positive for epithelial and smooth muscle markers, whereas SFT is negative for those markers (6). Myofibroblastoma may mimic SFT, but

Table I: A review of the vaginal SFT cases in the literature

\begin{tabular}{|c|c|c|c|c|c|c|}
\hline Author & Age & $\begin{array}{c}\text { IHC } \\
\text { (+) markers }\end{array}$ & $\begin{array}{c}\text { IHC } \\
\text { (-) markers }\end{array}$ & $\begin{array}{c}\text { Mitotic } \\
\text { index }\end{array}$ & $\begin{array}{c}\text { Ki-67 Proliferation } \\
\text { index }\end{array}$ & Follow-up \\
\hline $\begin{array}{l}\text { Akiyama Y } \\
\text { et al. (3) }\end{array}$ & 34 & $\begin{array}{l}\text { CD 34, } \\
\text { Vimentin, } \\
\text { bcl-2 }\end{array}$ & $\begin{array}{l}\text { EMA, Cytokeratin, S100, } \\
\text { NSE, SMA, CD68 }\end{array}$ & $<1 / 50 \mathrm{HPF}$ & $<1 \%$ & - \\
\hline $\begin{array}{l}\text { Vadmal MS } \\
\text { et al. (4) }\end{array}$ & 66 & $\begin{array}{c}\text { CD } 34, \text { bcl-2, } \\
\text { CD } 99\end{array}$ & SMA, MSA, S10011 & $\begin{array}{c}\text { Not } \\
\text { available }\end{array}$ & - & - \\
\hline $\begin{array}{l}\text { Iyengar P } \\
\text { et al. (5) }\end{array}$ & 52 & $\begin{array}{c}\text { CD 34, } \\
\text { Vimentin, bcl- } \\
\text { 2, ER, PR }\end{array}$ & $\begin{array}{c}\text { CD99, SMA, MSA, S100, } \\
\text { GFAP, EMA, Myoglobin, } \\
\text { Low-molecular weight } \\
\text { keratin }\end{array}$ & $\begin{array}{c}\text { Not } \\
\text { available }\end{array}$ & - & $\begin{array}{l}2 \text { local recurrences } \\
\text { after first excision } \\
(10-29 \text { months })\end{array}$ \\
\hline $\begin{array}{l}\text { Placide N } \\
\text { et al. (6) }\end{array}$ & 48 & $\mathrm{CD} 34, \mathrm{bcl}-2$ & $\begin{array}{l}\text { Cytokeratin AE1/3, } \\
\text { CAM 5.2, EMA, SMA, } \\
\text { S-100, Desmin, CD99 }\end{array}$ & $\begin{array}{c}\text { Not } \\
\text { available }\end{array}$ & - & $\begin{array}{l}\text { Free of disease } \\
6 \text { years after the } \\
\text { excision }\end{array}$ \\
\hline Recent Case & 25 & $\begin{array}{l}\text { CD 34, bcl-2, } \\
\text { Vimentin }\end{array}$ & $\begin{array}{l}\text { CD99, SMA, S100, } \\
\text { EMA, HMB-45 }\end{array}$ & $\begin{array}{l}\text { Up to 4/ } \\
\text { HPF }\end{array}$ & $8 \%$ & $\begin{array}{c}\text { Local recurrence } \\
\text { after first excision } \\
\text { (4 years })\end{array}$ \\
\hline
\end{tabular}

IHC: Immunohistochemistry. 
myofibroblastoma of the lower genital tract is positive for desmin, SMA, and estrogen-progesterone receptors (6).

Typically, a SFT is positive for vimentin and CD34. Other antigens frequently expressed by lesional cells include bcl2 and CD99. Strong desmin, S-100 and CD68 expressions may help exclude a lesion from SFT category. Our lesion's immunohistochemical profile is consistent with SFT.

The criteria for predicting malignant clinical behavior (local recurrence or distant metastases) include the following: large tumor size (more than $5 \mathrm{~cm}$ ), infiltrative margins, high cellularity, nuclear pleomorphism, areas of tissue necrosis and increased mitotic index (more than 4 mitosis in $10 \mathrm{HPF}$ ) and these factors should be included in the pathology report (7-9). In our case, the high cellularity and the increased mitotic index about 4 mitotic figures per each high power field were the features suggestive of a malignant behavior in the recurrent tumor. In a recent article published by Demicco et al., the authors clinicopathologically analyzed 110 cases of solitary fibrous tumor (primary soft tissue: 79 cases, and pleural solitary fibrous tumors: 31 cases), and suggested a risk stratification model based on age, size, and mitotic index (10). According to this model a 3-tiered model stratifying the patients by overall risk of metastasis (low, moderate, or high) was developed. Scores were assigned for age $(<55$ : score 0 vs. $\geq 55$ : score 1$)$, tumor size $(<5$ : score 0,5 to $<10$ : score 1,10 to $<15$ : score 2 , or $\geq 15 \mathrm{~cm}$ : score 3 ), and mitotic figures $/ 10$ high power fields (0: score $0,1-3$ : score 1 , or $\geq 4$ : score 2 ), and total scores calculated to determine the risk of aggressive disease. The overall risk of metastasis is predicted to be low if the total score is $0-2$, moderate for 3-4 and high for 5-6 (10). According to these criteria our case had a score 2 and the overall risk of metastasis was predicted to be low.

We could not detect any distinguishing organelle suggestive of a specialized line of differentiation by transmission electron microscopy as was reported previously by Ide et al in some of their cases (11). They suggest that SFT probably originates from perivascular stem cells which can differentiate along 3 evolutional lines as endothelial, pericytic, and fibroblastic by following a pathway that occurs in normal angiogenesis (11).

The behavior of SFT is unpredictable. The relationship between morphology and outcome is not always clear cut. Some "malignant" tumors behave in a benign fashion while some morphologically "benign" lesions behave aggressively. In addition to the presence of histological criteria of malignancy, the absence of sclerotic-hypocellular areas and a tumor size of more than $10 \mathrm{~cm}$ suggest a poor outcome and these cases may deserve close follow-up (9). The tumor in our case recurred 4 years after the first excision.
However, distant metastases were not detected. The patient is alive and well today, 7.5 years after her second operation.

In conclusion, we have described a case of primary SFT of vagina with malignant histological features. We believe this is the first case displaying these features as reported in the literature. The typical histological appearance of the tumor, the electron microscopic characteristics and the confirmatory immunohistochemical panel aided in the diagnosis. Despite the fact that SFT is rare in the female genital tract, it should always be considered in the differential diagnosis of lesions showing fibroblastic, muscular, neural, and myofibroblastic differentiation. Most SFTs are said to behave in a benign fashion after complete excision. However, patients should be followed up closely due to the unpredictable clinical behavior. This is especially important for tumors that display unusual gross or histological features like those described in our case.

\section{REFERENCES}

1. Suster S, Nascimento AG, Miettinen M, Sickel JZ, Moran CA. Solitary fibrous tumors of soft tissue. A clinicopathologic and immunohistochemical study of 12 cases. Am J Surg Pathol. 1995;19:1257-66.

2. Nascimento AG. Solitary fibrous tumor: An ubiquitous neoplasm of mesenchymal differentiation. Adv Anat Pathol. 1996;3:388-95.

3. Akiyama $\mathrm{Y}$, Nabeshima $\mathrm{K}$, Koita $\mathrm{H}$, Yamanaka M, Koono M. Solitary fibrous tumor of the vagina. Pathol Int. 2000;50:327-31.

4. Vadmal MS, Pellegrini AE. Solitary fibrous tumor of the vagina. Am J Dermatopathol. 2000;22:83-6.

5. Iyengar P, Ismiil ND, Gerber D, Khalifa MA. Vaginal solitary fibrous tumor: A case report with recurrence after incomplete excision. J Low Genit Tract Dis. 2007;11:50-4.

6. Placide N, Robert S. Solitary fibrous tumor of the vagina: A case report with review of the literature. Int J Surg Pathol. 2012;20(1):101-4

7. Hasegawa T, Matsuno Y, Shimoda T, Hasegawa F, Sano T, Hirohashi S. Extrathoracic solitary fibrous tumors: Their histological variability and potentially aggressive behavior. Hum Pathol. 1999;30:1464-73.

8. Vallat-Decouvelaere AV, Dry SM, Fletcher CD. Atypical and malignant solitary fibrous tumours in extrathoracic locations: evidence of their comparability to intra-thoracic tumours. Am J Surg Pathol. 1998;22:1501-11.

9. Gold JS, Antonescu CR, Hajdu C, Ferrone CR, Hussain M, Lewis JJ, Brennan MF, Coit DG. Clinicopathologic correlates of solitary fibrous tumors. Cancer. 2002,94:1057-68.

10. Demicco EG, Park MS, Araujo DM, Fox PS, Bassett RL, Pollock RE, Lazar AJ, Wang WL. Solitary fibrous tumor: A clinicopathological study of 110 cases and proposed risk assessment model. Mod Pathol. 2012;25:1298-306.

11. Ide F, Obara K, Mishima K, Saito I, Kusama K. Ultrastructural spectrum of solitary fibrous tumor: A unique perivascular tumor with alternative lines of differentiation. Virchows Arch. 2005;446:646-52. 